\title{
Palmar and digital dermatoglyphic traits of Kenyan and Tanzanian subjects
}

\author{
*P. S. Igbigbi and B. C. Msamati \\ Department of Anatomy, \\ College of Medicine, University of Malawi, \\ Private Bag 360, Chichiri, Blantyre 3, Malawi \\ E-mail; pigbigbi@yahoo.com.
}

\begin{abstract}
Summary
Dermatoglyphic traits, along with other morphological, molecular and biochemical markers have traditionally been used in biological anthropology to explore affinities and differences among human groups.

Methodology: We carried out a cross-sectional study of healthy able-bodied volunteers of indigenous Kenyan and Tanzanian subjects to establish their palmar and digital dermatoglyphic traits, by counting and classifying their ridge pattern configurations of arches, loops, whorls and ridges based on standard techniques.

Results: Ulnar loops were the most prevalent digital ridge patterns and arches were the least in our samples with significant sex differences exhibited in arches, ulnar loops and whorls $(P<0.05)$. Similarly, men had significantly higher TFRC than women in Kenyans $(P<0.001)$, while Tanzanians showed no sex difference $(P<0.5)$. Women, however, had higher PII than men in Kenyans but the reverse was true in Tanzanians. In both groups, men showed significantly higher mean $a-b$ ridge counts than women $(P<$ 0.001 , Kenyans; $<0.01$, Tanzanians), and women showed greater mean atd angles than men $(P>0.5)$. The TFRC, atd angle and $a-b$ ridge count were significantly different between Kenyans and Tanzanians $(\mathrm{P}<\mathbf{0 . 0 0 1})$.

Conclusion: This study documents probably for the first time the normal and comparative dermatoglyphic traits of two East African populations, indicating that Tanzanians are dermatoglyphically closer to Malawians than Kenyans.
\end{abstract}

\section{Keywords: Palmar dermatoglyphics, East Africans}

\section{Résumé}

Les traits dermatoglyphiques, avec d'autres marqueurs morphologiques, biochimiques et moleculaires ont été utilisés traditionnellement dans l'anthropologie biologique afin d'étudier les affinités et les écarts parmi les groupes humains. Méthodologie: Nous avons effectué une étude coupe transversale des sujets volontaires forts et en bonne santé d'origine de Kenya et la Tanzanie afin d'établir leurs traits dermatoglyphiques digitals et palmar dénombrement et la classification de leur tendance de configuration de la crête de voûtes, boucles, verticille et voûtes fondés sur les techniques standards.

Résultats: Boucles cubitus étaient les tendances crêtes digitales les plus fréquentes et les voûtes étaient les moindres dans nos échantillons avec un écart sexe important montré dans les voûtes, boucles cubitus et verticille $(P<0,05)$, pareillement, les hommes avaient le TFRC remarquablement plus élevé plus que les femmes chez des Kenyans $(\mathrm{P}<0,001)$, tandis que les Tanzanians n'ont pas montré aucun écart en ce qui est du sexe $(P<0,05)$. Toutefois, des femmes avaient Pl1 plus éléve que des hommes chez des Kenyans mais c'est le contraire chez les Tanzanians. Chez les deux groupes, des hommes avaient montré compte $a$ - b crète moyenne remarquablement plus élevée plus que chez des femmes ( $P$ $<0,001$, Kenyans; $<0,01$, Tanzanians), et des femmes avaient montré angles atd moyen plus que chez des hommes ( $\mathrm{P}>$ $0,5)$. Le TFRC, angle atd et compte $a-b$ crête étaient remarquablement différents entre Kenyans et Tanzanians ( $P$ $<0,001)$.

Conclusion: Il est probable que pour le premier fois, cette étude montre en détail les traits dermatoglyphiques moyens et comparés des deux populations de l'Afrique orientale, indiquant que des Tanzanians sont dermatoglyphiquement plus proche des Malawians plus que des Kenyans.

\section{Introduction}

Analysis of fingerprints from the point of view of personal identification is well known. In principle it focuses on the ridges formed by the raised apertures of sweat glands that have unique detailed formations, are much less fortuitous in origin and have anatomical regularities ${ }^{1}$. The science of these ridges is known as dermatoglyphics. Dermatoglyphic traits, along with other morphological, molecular and biochemical markers have traditionally been used in biological anthropology to explore affinities and differences among human groups. In contrast to monogenic polymorphisms, dermatoglyphics are polygenic traits under possible environmental influences that are restricted to the first months of embryonic life ${ }^{2}$. There are also normal variations in these traits, which represent hereditary differences between members of separate populations and members of the same population or family ${ }^{1}$. Thus, dermatoglyphic traits are most useful in studying population dynamics ${ }^{3}$.

Studies on Caucasians ${ }^{4-6}$ have demonstrated that dermatoglyphic traits could be used in tracing the history and relationships of population. In this connection, Wilder ${ }^{7}$ showed that racial differences existed in the palm and finger configuration of Germans, European-Americans, Chinese and Japanese. The distribution of finger print characteristics in Whites and Negroes living in Brazil have also been documented and the most marked difference observed between Whites and the total Negroid group was in the prevalence of radial loops ${ }^{8}$. These results are further testimony of the usefulness of dermatoglyphic traits in population study.

Several studies in sub-Saharan African populations have further demonstrated the existence of dermatoglyphic differences between various ethnic and population groups ${ }^{9-16}$. Yet despite their usefulness, there are only two published reports on East Africans - one for the Hehe Bantu-speaking tribe of southern highlands of Tanzania ${ }^{17}$, and the other examined the associations between dermatoglyphic variation, topography, and climate in Kenya ${ }^{18}$. However, apart from these reports no dermatoglyphic study has compared the 
two neighbouring East African countries whose common language is Kiswahili.

Kenya with an area of $582,600 \mathrm{sq} \mathrm{km}$ is bounded by Sudan and Ethiopia to the north, Somalia and the Indian Ocean to the east, Tanzania to the south and Uganda to the west. Linguistically it belongs to the Niger-Congo language group 19. Uganda and Kenyan on the other hand bound Tanzania to the north, the Indian Ocean is to the east, Mozambique, Malawi and Zambia to the south, and the Democratic Republic of Congo, Burundi, Rwanda and Lake Tanganyika to the west. It has an area of $945,000 \mathrm{sq} \mathrm{km}$ and linguistically belongs mainly to the Niger-Congo language group. The objective of this study is to establish the normal finger and palmar dermatoglyphic features of Kenyan and Tanzanian subjects, in order to explore their affinities and differences, if any, since they belong to the same linguistic group.

\section{Materials and methods}

Altogether 304 Kenyans, 164 males and 140 females aged 12 - 14 years from Nairobi Primary School and 300 Tanzanians, 180 males and 120 females aged $19-25$ years students of Muhimbili University College of Health Sciences were studied. The subjects were healthy able-bodied volunteers whose parents and grandparents were indigenous Kenyans or Tanzanians, respectively, selected from the cosmopolitan cities of Nairobi and Dar-es-Salaam. This provided a good mixture of social backgrounds to allow for the inclusion of quantitative palmar variables ${ }^{20}$. All subjects were asked individually if there was any non-Kenyan or Tanzanian contribution to their ancestry for as far back as they knew, and anyone who gave a positive answer was excluded. In the case of related individuals in the sample, only the print of one of them was included to avoid statistical distortion of occurrences of particular features in a relatively small sample ${ }^{21}$.

Bilateral finger and palmar prints were obtained and the pattern configurations were classified according to Cummins and Midlo's ${ }^{22}$ standard technique. Only clear prints were classified into arches, loops and whorls (Fig. 1). Ridge counts were made according to the method described by Holt ${ }^{2}$. Inter-observer variations in counting were eliminated as one 'blinded' person who did not collect the prints examined them all with the aid of a magnifying lens. The following features were examined:

The total finger ridge counts (TFRC) are the sum of the ridge-counts (largest count only when there is more than one) on all ten fingers for each sex.

Pattern intensity index (PII) is the mean number of triradii formed on digits per individual subject, and it was calcu- lated from the totals of the pattern type frecuency. This reflects the complexity of the finger patterns in an individual or population. In this system, arches having nc triradius are scored 0 ; loops representing pattern formation $v /$ ith one triradii are scored 1; and whorls or composite patterns with two (or more) triradii are scored 2. The pattern frequency of a population is therefore summarised by the fing 2 pattern intensity representing the mean number of digital triradii per person.

The atd angle is the angle between two straight lines joining the radial (a) and ulnar (d) triradii to th: hypothenar triradius (t), (Fig. 1).

The $a-b$ ridge count represents the number of ridges between triradii (a) and (b) (Fig. 1)

The ridge patterns, TFRC, PII, atd angle a ad a-b ridge counts were analysed statistically using Chi-squire tests with 2 degree of freedom for ridge patterns and sturlent's t-tests for matched or unmatched pairs as appropriate or the other parameters. The data obtained for Kenyan an 1 Tanzanian subjects were then compared with findings for Malawians obtained previously using similar methods.

\section{Results}

Palmar ridge patterns: The overall distribution of the palmar patterns on both hands of each sex was not significantly different $(\mathrm{p}>0.5)$.

Digital ridge patterns: Ulnar loops were the mc st prevalent finger ridge patterns and arches were the least type in the sampled populations. Significant sex differences were exhibited in arches, ulnar loops and whorls in tie sampled populations $(\mathrm{p}<0.05$, Table 1$)$.

Table 2 shows the mean total finger ridge cor nt (TFRC), mean atd angles, mean $a-b$ ridge counts and pattern intensity index (PII) by sex. There was significant sex $\mathrm{d}$ fference in TFRC in Kenyans $(P<0.01)$ but none in Tanzan an subjects $(p>0.5)$. In both groups men showed significıntly higher mean a-b ridge counts than women ( $p>0.001$, Kenyans; $p<$ 0.01 , Tanzanians). Women had higher mean atd angles than men in both groups but the differences were not :tatistically significant $(\mathrm{p}<0.5)$. Women had also higher PII t lan Kenyan men and the reverse was the case in Tanzanians.

Table 3 compares the dermatoglyphic traits (I Kenyans, Tanzanians and of Malawians previously reporte $\mathrm{d}^{23}$. There were significant differences between Kenyans and Tanzanians with respect to TFRC, atd angle and a-b ridge counts (p<0.001). Similar significant differences also e cisted in all the above parameters between Malawians and both Kenyans and Tanzanians $(\mathrm{p}<0.001)$.

Table 1 The percentage frequency of digital ridge patterns of Kenyan and Tanzanian subjects

\begin{tabular}{|c|c|c|c|c|c|c|c|c|c|c|c|c|}
\hline \multirow{3}{*}{$\begin{array}{l}\text { Ridge } \\
\text { Pattern } \\
\text { Types }\end{array}$} & \multicolumn{6}{|c|}{ Kenyan } & \multicolumn{6}{|c|}{ Tanzanian } \\
\hline & & Male & & & Female & & & Male & & & Femal: & \\
\hline & Left & Right & Mean & Left & Right & Mean & Left & Right & Mean & Left & Rigl t & Mean \\
\hline Arch & 5.71 & 4.28 & 4.99 & 3.16 & 2.63 & 2.89 & 5.11 & 4.67 & 4.89 & 3.33 & 3.33 & 3.33 \\
\hline $\begin{array}{l}\text { Radial } \\
\text { loop } \\
\text { Ulnar }\end{array}$ & 6.25 & 6.42 & 6.34 & 6.32 & 7.11 & 6.71 & 6.67 & 7.04 & 6.86 & 7.50 & 7.50 & 7.50 \\
\hline loop & 69.05 & 76.19 & 72.62 & 69.12 & 70.18 & 69.65 & 65.56 & 68.89 & 67.22 & 79.17 & 70.83 & 75.00 \\
\hline Whorl & 18.99 & 13.11 & 16.05 & 21.40 & 20.08 & 20.75 & 22.66 & 19.40 & 21.03 & 10.00 & 18.34 & 14.17 \\
\hline
\end{tabular}


Table 2 The total finger ridge count (TFRC), atd angle, a-b ridge counts and Malawian women in atd angle differed ( $p<$ pattern intensity indices of Kenyan and Tanzanian subjects

\begin{tabular}{|c|c|c|c|c|c|c|}
\hline \multirow[t]{2}{*}{ Variables } & \multicolumn{3}{|c|}{ Kenyan } & \multicolumn{3}{|c|}{ Tanzanian } \\
\hline & Male & Female & $\mathbf{P}$ & Male & Female & $\mathbf{P}$ \\
\hline \multicolumn{7}{|l|}{ TFRC } \\
\hline Mean & 125.60 & 116.26 & \multirow[t]{2}{*}{$<0.01$} & 115.05 & 114.9 & \multirow[t]{2}{*}{$>0.5$} \\
\hline $\begin{array}{l}\text { SD } \\
\text { atd angle }\end{array}$ & 39.0 & 32.16 & & 32.14 & 32.50 & \\
\hline Mean & 85.20 & 86.78 & \multirow[t]{2}{*}{$<0.1$} & 77.98 & 78.00 & \multirow[t]{2}{*}{$<0.0$} \\
\hline SD & 10.24 & 11.50 & & 8.86 & 7.22 & \\
\hline \multicolumn{7}{|c|}{$a-b$ ridge count } \\
\hline Mean & 89.60 & 87.00 & \multirow[t]{2}{*}{$<0.001$} & 85.42 & 83.42 & \multirow[t]{3}{*}{$<0.0$} \\
\hline SD & 15.36 & 17.34 & & 19.80 & 18.90 & \\
\hline PII* & & & & & & \\
\hline Mean & 7.94 & 8.91 & & 8.23 & 7.09 & \\
\hline
\end{tabular}
$0.01)$. The TFRC in females was higher in Malawians, high in Kenyans and least in Tanzanians; for men it was higher in Kenyans, high in Malawians and least in Tanzanians. The atd angle was higher in Kenyans, high in Tanzanians and least in Malawians; a similar trend emerged with the $\mathrm{a}-\mathrm{b}$ ridge counts. The PII of Kenyans was closer to the indices of Tanzanians than those of Malawians (Table 3).

\section{Discussion}

$P I I^{*}$ were calculated from pattern type frequency totals, hence standard deviations were not obtained.

Our study has demonstrated that palmar patterns do not exhibit sexual dimorphism and may therefore not differentiate

Table 3 A comparison of dermatoglyphic variables between Kenyan, Tanzanian population groups. Previous studies in and Malawian subjects

\begin{tabular}{|c|c|c|c|c|c|c|}
\hline \multirow[t]{2}{*}{ Variables } & \multicolumn{2}{|c|}{ Kenyan (2001)+ } & \multicolumn{2}{|c|}{ Tanzanian (2001)+ } & \multicolumn{2}{|c|}{ Malawians (1999)++ } \\
\hline & Male & Female & Male & Female & Male & Female \\
\hline \multicolumn{7}{|l|}{ TERC } \\
\hline Mean & 125.60 & 116.26 & 115.05 & 114.9 & 123.72 & 140.15 \\
\hline $\mathrm{SD}$ & 39.0 & 32.16 & 32.14 & 32.50 & 39.82 & 48.70 \\
\hline $\begin{array}{l}\mathrm{n} \\
\text { atd angle }\end{array}$ & 164 & 140 & 180 & 120 & 89 & 142 \\
\hline Mean & 85.20 & 86.78 & 77.98 & 78.00 & 72.06 & 80.66 \\
\hline SD & 10.24 & 11.50 & 8.86 & 7.22 & 8.30 & 8.50 \\
\hline \multicolumn{7}{|c|}{$a-b$ ridge count } \\
\hline Mean & 89.60 & 87.00 & 85.42 & 83.42 & 79.74 & 64.66 \\
\hline SD & 15.36 & 17.34 & 18.90 & 6.30 & 16.88 & 13.22 \\
\hline \multicolumn{7}{|l|}{ PII* } \\
\hline Mean & 7.94 & 8.91 & 8.23 & 7.09 & 7.65 & 6.66 \\
\hline
\end{tabular}

$P I^{*}$ were calculated from pattern type frequency totals, hence standard deviations were not obtained. (Sources: +Present study; ++Igbigbi and Msamati 1999. Note the same methods were employed in both studies.)

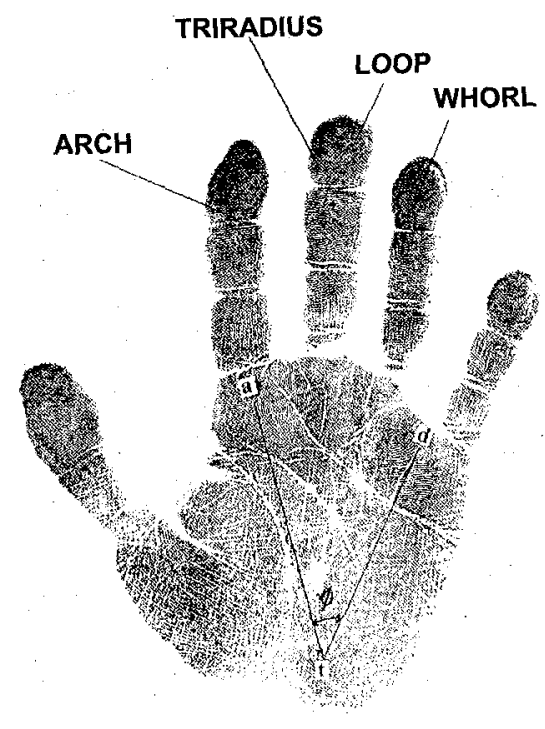

Fig. 1 Palmar and digital prints illustrating arches, loops, whorls, triradii and atd angle

However, the level of significance between Malawian and Tanzanian men in TFRC, and between Tanzanian and
Africans ${ }^{12},{ }^{15-16}$ and Caucasians ${ }^{24-25}$ do support this view. The Chorote Indians have also demonstrated the lack of sexual dimorphism in palmar pattern types ${ }^{26}$. The present study has also shown the prevalence of digital ulnar loops followed by whorls as, indeed, was the case with other African populations studied 12, 15, 16, 28, 29 . However, Kenyan men had more ulnar loops than women, as is the case with the Zulus of South Africa ${ }^{29}$. This is an interesting finding for a number of reasons. It emphasises that prints of the finger and palmar surface provide a distinct technical record in physical anthropology ${ }^{30}$ because they have greater phylogenetic stability ${ }^{31}$. However, in Caucasians, high frequencies of digital arches and radial loops in both sexes have been reported ${ }^{24}$. These findings underline the usefulness of digital patterns in differentiating population groups. In this connection, De Sa Benevides and Salzano ${ }^{8}$ had also shown that the most marked difference between Whites and the total Negroid group was the prevalence of radial loops in the latter than the former. In another study on the Hehe tribe of Tanzania it was shown that the finger pattern types of women showed rather greater than usual elevation in the total frequency of loops and a diminution in whorls ${ }^{17}$, which was also shown in this study. As far as we known the only other female sample with high loop frequency was in Mozambique 17. The present study has also demonstrated a higher frequency of loops in both sexes of both groups, suggesting dermatoglyphic similarity between Kenyans and Tanzanians.

Our study has demonstrated sexual dimorphism in TFRC in Kenyans but none in Tanzanians. However, in both groups the 
mean TFRC was higher in men than women. This is the opposite of what was reported in Malawians ${ }^{23}$ but it was in agreement with what was reported among valley Basques when compared with other Spaniards ${ }^{24}$. A previous study had indeed shown that racial differences do exist between Africans and Caucasians in mean TFRC ${ }^{24}$. Other authors have also demonstrated that the mean TFRC was lower in African than in British samples but the difference was most marked in men ${ }^{28}$. Our findings tend to suggest that mean TFRC can also differentiate African population groups. Differences in total ridge count frequencies between different populations may also be expected, since the frequencies of arches, loops and whorls vary between races ${ }^{28}$.

Moreover, we have shown that the PII was higher in Kenyan women than men but the reverse was the case in Tanzanian and Malawian subjects (Table 3). This may indicate a closer dermatoglyphic link between Malawians and Tanzanians. The mean atd angle was also found to be higher in women than men in our study but the differences were not statistically significant, thus confirming the reports in other populations ${ }^{15,16,23,28}$. The mean a-b ridge count was significantly higher in men than women ( $\mathrm{p}<0.001$ Kenyans; $\mathrm{p}<$ 0.01 Tanzanians) as was the case with Malawians, contrary to what was shown in Caucasians, suggesting racial differences ${ }^{32}$. Pons ${ }^{32}$ demonstrated that racial differences existed in human palms with those of white populations varying between 80 and 86 ridges, black populations, between 74 and 80 , the Indian subcontinent between 68 and 80 and American Indians between 80 and 90 . In our study, we found ridge counts of between 87 and 90 for Kenyans and between 83 and 86 for Tanzanians. These values are, however, higher than those of Southern African populations previously studied by Blecher ${ }^{28}$ Pons ${ }^{32}$, and Malawians ${ }^{23}$ (64 and 80 ) we reported previously. Notwithstanding this, it is worth noting that the values quoted for Africans by Pons may be more accurate for West Africans as Igbigbi et a ${ }^{15,16}$ had shown in the Yorubas, Ibos, Hausas and Urhobos of Nigeria. The significant differences $(\mathrm{p}<0.001)$ in dermatoglyphic parameters between Kenyan and Tanzanian subjects as well as between Malawians, Kenyans and Tanzanians (Table 3) further indicate the usefulness of dermatoglyphic traits in studying population dynamics as Chai ${ }^{3}$ had also demonstrated.

Finally, we have presented the normal dermatoglyphic palmar and digital traits of Kenyan and Tanzanian subjects. In our comparison, we have shown that both groups have some digital dermatoglyphic traits that are similar while also demonstrating traits that are different as shown in other African studies $15,16,23,28,29$. When both groups were compared with Malawians, our findings suggest that dermatoglyphically, Tanzanians appear to be closer to Malawians than to Kenyans. This finding could be explained on dermatoglyphic distance between Kenyans and Malawians despite their linguistic similarity, the Niger-Congo language grouping. However, it must be pointed out that Kenyans and Tanzanians have adopted Kiswahili as a common language in addition to their many dialects. The admixture of some Kiswahili words from Arabic, Chinese and Portuguese ${ }^{19}$ and the fact that dermatoglyphic finger and palmar taxonomic traits show relationships with climate and altitude ${ }^{18}$, could also explain some of the de matoglyphic differences highlighted in our study.

\section{References}

1. Penrose LS: Fingerprints, palms and chromos mes. Nature 1963; 197: $933-938$.

2. Holt SD: Quantitative genetics of finger print patterns. Brit Med Bull 1961; 17: $247-250$

3. Chai CK: Analysis of palm dermatoglyphics in Taiwan Indigenous populations. Am J Phys Anthropol 19; 1; 34: 369 376.

4. Meier RJ: Anthropological dermatoglyphics: A review Yearbook of Phys Anthropol 1980; 23: 147 - 178.

5. Froehlich JW and Giles EA: Multivariate apprc ach to fingerprint variation in Papua New Guinea. Implication for prehistory. Am J Phys Anthropol 1981b; 54: 73 - 91

6. Jantz RL and Chopra VP: A comparison of deimatoglyphic methodologies in population studies. Am J Ph/s Anthropol 1983; 60: $61-67$.

7. Wilder HH: Racial differences in palm and sole $\mathrm{c}$ onfiguration: palm and sole prints of Japanese and Chinese. Am J Phys Anthropol 1925; 6: 143 - 206.

8. De Sá Benevides FR and Salzano FM: Fingerpri its of Whites and Negroes form Southern Brazil. Am J Phy Anthropol $1969 ; 31: 59-64$.

9. Boroffice RA: Digital dermatoglyphic patterns i t a sample of the Nigerian population. Am J Phys Anthropol :978; 49:167 -170 .

10. Jantz RL and Brehme $\mathrm{H}$ : Finger and palmar derr tatoglyphics of a Yoruba (Nigeria) sample. Ann Hum Biol 1978; 5: 539 546.

11. Jantz RL and Hawkinson $\mathrm{CH}$ : Finger ridge coun s variability in sub-Saharan Africa. Ann Hum Biol 1979; 6: 41 - 53.

12. Jantz RL, Hawkinson $\mathrm{CH}$, Brehme $\mathrm{H}$ and Bitzero h HW: Finger ridge count variation among various sub Saht ran African groups. Am J Phys Anthropol 1982; 57: 311 - 321.

13. Jantz RL: Anthropological dermatoglyphic resiarch. Ann Rev Anthropol 1987; 16: 161 - 177.

14. Hunt DR: Dermatoglyphic variation among sub-S tharan African: a multivariate analysis of population structure. Ph.D. Dissertation, University of Tennessee, USA.

15. Igbigbi P S, Didia BC, Agan TU and Ikpae BE: Palmar and digital dermatoglyphics in two ethnic communitie in Nigeria. West Afr J Anat 1994; 2: 52 - 56.

16. Igbigbi PS, Didia BC, Owhojedo and Obochi O: Comparative palmar and digital dermatoglyphics of Hausa and 1 Jrhobo ethnic groups in Nigeria. West Afr J Anat 1996; 4: 51 - 56.

17. Roberts DF, Chavez J and Redmayne A: Dermatc glyphics of 
the Hehe (Tanzania) Man 1974; 4: 31-43.

18. Rosa P: Associations between dermatoglyphic variation, to pography, and climate in Kenya. Am J Phys Anthropol 1985; 68: $395-408$

19. Upshall M: Kenya, Tanzania. In: Hutchinson Encyclopaedia Oxford: Helicon Publishing 1992 (ed), 10 th ed. pp 579 - 580, $1012-1013$

20. Reed I. Review: Dermatoglyphics in Medicine - Problems and use in suspected chromosome abnormalities. Am J Hum Gen 1981; 8: $411-429$.

21. Cummins $\mathrm{H}$ and Midlo $\mathrm{C}$ : Palmar and plantar epidermal ridge configurations (Dermatoglyphics) in European-Americans. Am J Phys Anthropol 1926; 9: 471 - 502.

22. Cummins $\mathrm{H}$ and Midlo $\mathrm{C}$ : Finger prints, palms and soles an introduction to dermatoglyphics. Philadelphia: The Blakiston Co 1943. Chapter XI, 309.

23. Igbigbi PS and Msamati BC: Palmar and digital dermatoglyphic patterns in Malawian subjects. East Afr Med J 1999; 76: 668 -671 .

24. Arietta MI, Ibarrondo M and Lustao C: Digital dermatoglyphics in the Basque population. Univariate and multivariate comparison with other Spanish populations. Am J Phys Anthropol
$1987 ; 73: 89-98$

25. Greally MG, Roberts DF: A study of digital dermatoglyphics in Ireland. Ann Hum Biol 1991; 18: 485 - 496.

26. Arrieta MI, Criado B, Martinez B, Simon A, Salazar L and Lostao CM: Characterization of digital dermatoglyphic features in Salazar Valley: Comparison with other Basque Valleys, Ann Hum Biol 1991; 18: 221 - 233.

27. Dermachi DA and Seisdedos L: Dermatoglyphics of the Chorote Indians and their relationships with other inhabitants of the Gran Chaco. Ann Hum Biol 1996; 23: 363 - 371 .

28. Blecher SR: Dermatoglyphics of the Pandamatenga BushBantu hybrids. Hum Heredity 1972; 22: 149 - 170.

29. Grace HJ and Ally FE: Dermatoglyphics of the South African Negro. Hum. Heredity 1972; 22: $149-170$.

30. Cummins H: Dermatoglyphic prints: Neglected records in racial anthropology. Am J Phys Anthropol 1931; 16: 31 - 40

31. Froehlich JW and Giles E: Multivariate approach to fingerprint variation in Papua New Guinea. Perspectives on the evolutionary stability of dermatoglyphic markers. Am J Phys Anthropol 1981a; 54: $93-106$.

32. Pons J: Racial aspects of the $a-b$ ridge-count on the human palm. Anthropologischier Anzeiger, 1982; 40: 245 - 251. 